\title{
A Passport to Peace? Modern Tourism and Internationalist Idealism
}

\author{
SUNE BECHMANN PEDERSEN \\ Unit for Media History, Department of Communication and Media, Lund \\ University, Box 117, 22100 Lund, Sweden. Email: sune.bechmann_pedersen@, \\ kom.lu.se
}

Catchy slogans about tourism's peace-promoting qualities abound - 'passport to peace', 'a vital force for peace' and 'the peace industry', to name but a few. Yet, despite the critical scrutiny of the peace-tourism nexus in recent decades, its historical roots remain unexplored. This article traces the origins of the idea that tourism can help advance peace and international understanding. It examines the aspirations of the various international tourist organisations founded during the interwar and early post-war period. While these organisations sought to foster peaceful relations across national and cultural borders, their discourse of tourism as a force for peace also gave legitimacy to a transnational tourist industry and government attempts to secure hard currency in the Cold War.

\section{Tracing the origins of the 'peace industry'}

Tourism today has tremendous socio-economic importance. In 2016, the number of international arrivals was estimated to be 1.235 billion. Worldwide tourism receipts amounted to US\$1220 billion, and for many countries tourism accounted for the largest proportion of export earnings. On a global scale, tourism ranks as the third largest export category. The World Tourism Organization (UNWTO) forecasts that the global number of international tourist arrivals will reach 1.8 billion by 2030, up from just 25 million in 1950 (World Tourism Organization 2017). Tourism as a business and social practice has grown dramatically to become one of the most pervasive activities in today's world - an activity that has barely left anyone or any place on the planet untouched. It is often claimed that tourism is one of the largest industries in the world. However, the business is in fact so integrated, so dependent on a wide range of products and services, that it cannot be disentangled as a separate industry (Davidson 2005).

Given tourism's key role in shaping the modern world, it has been the target of resentful scorn as well as unbridled praise. 'Florence is nothing better than a vast 
museum full of foreign tourists,' Stendhal $(1959,317)$ snorted contemptuously in 1817. Half a century later, Dostoevsky made his first trip to Europe and observed 'the self-satisfied and completely mechanical curiosity of British tourists who look more at their guidebooks than at the curiosities' (Dostoevsky 1988, 26). The travellers' belittlement of others as mindless tourists is a trope with a long history, integral to the construction of self and other (Buzard 1993). As a growing number of affluent Europeans followed the beaten track of Grand Tour travellers through France and Italy, they made a highly noticeable impact along the way. Increased mobility augmented the awareness of cultural borders. However, it also created contact zones open to transgression and intercultural understanding.

Subsequent critics of tourism have taken aim at everything from its commodification and eradication of 'authentic' cultures to mass mobility's devastating effects on the local environment and the global climate. The tourist practice observed by Stendhal that 'each nationality brings with it its own manners and customs' continues to be a target of ridicule. Cultural critics have lamented the sun-and-sea tourist's disinterest in local traditions and the resulting 'McDonaldization' of the tourist experience in order to make the visitor feel at home anywhere in the world (Ritzer and Liska 1997). In this respect, mass tourism is just one factor in the greatly increased economic integration and human connectivity that undergirds the globalisation processes of the twentieth century. For these reasons, mass tourism has invited much of the same critique also levelled at globalisation in general (Osterhammel 2017). Its deriders see it as the neoliberal continuation of colonialism that exploits developing countries and thus contributes to global inequality (Vukonić 2012).

At the same time, however, intellectuals, academics, business professionals, and politicians have insisted for centuries that tourism is a benign force that fosters mutual understanding and helps bridge cultural differences. In tourism studies, this line of thinking has recently returned to favour. Scholars are striving to break with the excessive industry focus of much applied tourism research and instead revive the 'forgotten power of tourism as a social force' (Higgins-Desbiolles 2006). This strand of research is devoted to exploring how tourism can promote peaceful development in areas suffering from poverty and conflict. The agenda is clearly expressed in recent titles such as Tourism, Progress, and Peace (Moufakkir and Kelly 2010b) and Peace through Tourism (Blanchard and Higgins-Desbiolles 2013). The recent scholarly interest in how to unlock the positive forces of tourism comes after a period of considerable scepticism, when in response to two flagship events in particular the 1980 UNWTO Manila Declaration ('tourism can be a vital force for peace') and the 1988 conference 'Tourism - A Vital Force for Peace' - critically minded scholars questioned the underlying assumption that tourism was benevolent by default (Brown 1989; Litvin 1998).

However, the question no one on either side of the tourism-peace debate has asked is where the idea came from in the first place and how it gained such strength. For example, in their introduction to Tourism, Progress, and Peace, Moufakkir and Kelly (2010a, xxii) illustrate with a U-curve the 'changing views on the concept of peace through tourism'. Starting in 1980, the mood was euphoric. Having gone 
through phases of 'scepticism', 'disbelief', 'interest' and 'belief', the current mood is now 'excitement'. Where the euphoria originally came from does not appear to interest the authors.

The aim of the current article is thus to retrace the origins of the idea that tourism can serve as a force for peace. I begin by briefly examining the spurious logic that underpins the claim, tracing the notion to the internationalist idealism of the early twentieth century. By looking at the international institutionalisation of tourism, starting with the Congrès internationales des organisations officielles de tourisme in 1925, and continuing after the Second World War when tourist studies became an established discipline with a growing number of dedicated journals, I argue that the idea gained traction that tourism and peace went hand in hand - embodied in the popular catchphrase 'Peace through tourism' - because it suited a political agenda - a political agenda of using tourism for political ends in the post-war reconstruction of Western Europe and in the Cold War face-off with Communist Europe. This only grew stronger when recently independent developing countries decided that tourism was their path to prosperity. The catchphrase gave legitimacy and a human face to a transnational industry, and to the field of tourism studies, which was fighting for recognition among the more established disciplines, and for an air of importance.

\section{Tourism, Contact and Conflict}

In the run-up to the 'Tourism, A Vital Force for Peace' conference in 1988, one of the organisers published an article in the Journal of Travel Research. Under the title 'Tourism: The World's Peace Industry', the article announced that the conference built on the Manila Declaration, which 'challenged the industry with a concept of tourism that emphasises its social, cultural, economic, educational and political values' (D'Amore 1988, 35). The printed conference programme contained encouraging statements by Pope John Paul II, Ronald Reagan, and Mikhail Gorbachev (First Global Conference 1988, 5). The Pope's statement, originally part of a 1985 address to the World Travel Congress of the American Society of Travel Agents, reads: 'the encounters engendered among peoples through travel are not only a condition for the realisation of peace but a positive contribution towards peace' (John Paul II 1985). Reagan and Gorbachev's joint statement came from their Geneva summit in 1985: 'there should be greater understanding among our peoples and to this end we will encourage greater travel.'

Note, though, that these uplifting statements talk of travel. Not tourism. In a 1998 article critical of the peace-through-tourism discourse, Stephen Litvin took a swipe at this apparent discrepancy. Litvin opened with three similar tributes to travel by Gandhi, Kennedy and Reagan, and noted that what seems a small semantic difference (tourist versus traveller) is often of great importance in the scholarly literature (Litvin 1998). Litvin is of course correct in pointing to the careful studies of different travel modes and their varying engagement with locals. However, to claim an a priori difference between the tourist and other kinds of travellers amounts to 
essentialising 'the tourist' (Cohen 2004, 9-10). I would argue that tourism and travel are overlapping concepts, and so frequently used as synonyms that a critique of the peace-tourism nexus is best served by leaving them aside. After all, John Paul II spoke of 'tourism' ten times in his 1985 address while he only mentioned 'travel' four times. He called tourism a 'powerful potential for good', and stated that 'tourism has strengthened unity and fraternal solidarity between individuals and between nations'. Finally, he noted his appreciation of the ASTA attendees' efforts 'to cultivate human understanding and cultural enrichment through tourism' (John Paul II 1985). In this case, tourism and travelling fundamentally carry the same meaning.

In official UNWTO terminology, the traditional definition of a tourist is a person who spends more than 24 hours outside her or his country of residence, regardless of the journey's purpose. Such a definition is handy for statisticians, but offers less of a purchase to the historian who is exploring changing notions of travel and tourism over time. Tourism historians thus tend to define tourism more narrowly. One definition that has won broad acceptance is Rudy Koshar's characterisation of it as 'any practice arising from an individual's voluntary movement between relatively permanent "settledness" and an extended moment of leisured displacement' (Koshar 2000 , 8). This distinguishes leisure tourism from other kinds of travel, but in reality the boundaries are always blurry. Most business travellers seek out entertainment while they are away in order to make the trip more pleasurable, while being a 'tourist' has elements of routine labour such as photographing established sights. The literature on tourism as a vehicle for peaceful development tends to circumvent the differences between leisure travel and travel for other reasons. Similarly, the current article does not go into the matter, and applies the broader definition of tourism as synonymous with international travel. With this caveat in mind, the reasoning behind the idea that tourism produces peace can be scrutinised.

The logic behind the argument that tourism is a force for peace is underpinned by three assumptions, recently summarised by Renata Tomljenovic (2010, 17). First, it is assumed that tourism puts people in contact with one another. Second, it is assumed that this contact fosters mutual understanding and sympathy. Third, it is assumed that increased understanding and mutual friendship reduces conflict at a societal or international level. Building on Tomljenovic's analysis, I offer a critical review of the three assumptions.

The first assumption is obviously correct. It is difficult to travel and not encounter other people. However, such encounters tend to be brief and superficial. In fact, the advent of mass tourism relied largely on the reduction of friction and necessary interaction. The railways allowed for smoother, safer transport than stagecoaches. The jet age allowed for a quick relocation to a distant destination rather than spending days in close company with fellow travellers on a coach or a train. All-inclusive seaside hotels with modern amenities reduce interaction with locals to a minimum (Löfgren 1999). Niche tourism aside, the interactions between tourists and hosts are usually transient and without common goals beyond the conduct of simple transactions (Cohen 1984, 379). 
The second assumption - that contact fosters harmonious relations - rests on a crude reading of sociological contact theory. The contact theory made famous by Gordon Allport (1954) claimed that personal encounters could reduce inter-group hostility. Fifty years of research has indeed demonstrated the prejudice-reducing effect of contact (Hewstone and Swart 2011). However, given the fleeting nature of most tourist-local encounters, they hardly pass as substantial contact with hostility-reducing potential, and the mere proximity of locals and tourists does not suffice. In the words of the authors of a huge meta-study on contact theory research, 'proximity is a necessary but not sufficient condition for social contact. One cannot assume contact from the opportunity for contact' (Pettigrew and Tropp 2006, 755). Moreover, when tourists encounter locals, the result can just as well be conflicts over behavioural norms or limited resources.

The third assumption underpinning the peace-through-tourism argument maintains that improved interpersonal or inter-group relations will reduce tensions even at the broadest societal and international levels. A recent review of the tourism-peace nexus found little evidence for this claim. Although studies of tourism in post-conflict areas had claimed it has a positive effect on reconciliation processes, the review also found plenty of evidence that tourism can have negative effects on relations between traditional enemies (Farmaki 2017, 532-533). Recent research has also demonstrated that so many other factors influence international relations that no obvious correlation can be seen between relations at the individual or group level and international relations (Pratt and Liu 2016). As Litvin and many subsequent scholars critical of the peace-through-tourism argument have thus concluded, this logic is inverted. Tourism does not thrive in conflict zones. Rather, tourism's successful development presupposes the absence of conflict and negligible risks to the individual - 'In the absence of peace, it cannot, therefore, be a generator of peace' (Litvin 1998, 64). The unanswered question remains, however, as to where this idea came from in the first place.

\section{Internationalism and the International Tourist Organisations}

The idealisation of travel has a long history. Hans Christian Andersen's pronouncement 'to travel is to live' is just one of the innumerable famous quotes about the benefits of mobility and travel. Thomas Cook, the inventor of the package tour and the father of modern tourism, is said to have considered the railway a 'great and beneficial social force' (Higgins-Desbiolles 2006, 1193). Indeed, the first excursion he organised was for a group of temperance campaigners who wanted to attend a teetotal meeting in 1841. He later organised an excursion of English workers to Paris in support of a demonstration there. The idea that tourism could be a vehicle for international understanding and peace belongs to the broader current of cultural internationalism, which was on the rise in the late nineteenth and early twentieth centuries (Iriye 1997). The emergence of an increasingly affluent European and North American bourgeoisie with enough leisure time to travel abroad boosted 
international tourist traffic (Zuelow 2015). During this time of intensified cooperation across borders, a growing number of governmental and non-governmental international organisations also began to surface (Iriye 2002; Sluga 2013). Among them were international organisations to advance tourism and travel.

Curiously, the rise of international organisations devoted to the promotion and organisation of transnational tourism has barely been studied by historians of tourism and mobility. In the following, I shall therefore explore the origins of the earliest international tourism collaboration and the ideas that guided it. An international NGO of national touring clubs, the Ligue internationale des associations touristes, was founded in 1898 and revived after the First World War as the Alliance internationale de tourisme (AIT). In 1924, France invited governments and international tourist NGOs to form the Conseil central du tourisme. It was intended to coordinate tourism collaborations between governments and NGOs. However, the Conseil did not invite the national tourist organisations (NTOs), and its refusal to admit Germans antagonised many potential participants. ${ }^{1}$ Ultimately, according to a contemporary observer, it never achieved much (Lampe 1953, 155-156).

The real breakthrough in international tourism collaboration was pioneered by the European NTOs, which began to meet annually in 1925. In May 1925 in The Hague, 14 NTOs (including Germany's) met for the first Congrès internationales des organisations officielles de tourisme. The Dutch host, the liberal politician and professor Willem Treub, opened the meeting by warning that the European NTOs had hitherto spent too much time and energy competing against one another, instead of working and learning together. The main idea behind the congress was thus to share information and experiences about how to organise tourism in their respective countries. It was also to build peaceful relations between nations that had recently been at war. ${ }^{2}$ As Treub said, 'we know how war has made the means of knowing and valuing one another difficult'. The aim of the tourism representatives at the congress was therefore to 'work for a lasting peace'. ${ }^{3}$ Similar hopes attended the birth of the British Holiday Association. At its first meeting in 1929, it took as one of its objectives the promotion of international understanding (Richards 1995). In 1934, the Danish Ministry of Foreign Affairs' committee for the promotion of Denmark as a tourist destination also stressed that, from a political viewpoint, international tourism 'is a tool for developing the mutual acquaintance and thereby strengthening the mutual trust between nations." 4

The decades leading up to 1914 had seen the removal of many bureaucratic obstacles to international travel (Fahrmeir 2008). However, the outbreak of war led to the introduction of draconian measures that remained in place into the $1920 \mathrm{~s}$ (Zahra 2016, 38-39). Their dismantling became the objective of the European tourist

1. Danish National Archives (DNA), Udenrigsministeriet, Gruppeordnede sager 1909-1945, 90.C.12.

2. Het Vaderland (1925) Vreemdelingenverkeer, 4 May, evening edition.

3. Algemeen Handelsblad (1925) Congres voor vreemdelingenverkeer, 6 May, 5, morning edition.

4. DNA, Industrirådet 1934-1944, Sager vedr. Turistkommissionen, pk. 1934-36: Indledningsforedrag (n.d. [1934]), p. 1. 
experts. They also sought to establish international standards for the compilation of tourist statistics, and to have the widespread import duties on foreign tourism advertisements removed. Finally, the first congress broke new ground by agreeing to launch a joint European publicity campaign in North America. The eventual outcome of the campaign proved modest, but the idea of pooling the European advertisement resources nevertheless prepared the ground for the more ambitious and effective post-war tourism campaigns of the European Travel Commission and the Organization for European Economic Cooperation (Schipper et al. 2018).

The promotion of tourism as a vehicle for economic prosperity and peaceful development continued to guide the NTOs' international collaborations. In 1926 the collective effort to campaign for the development of tourism was made explicit by changing the title of the annual meetings to Congrès international des associations officielles de propagande touristique (Le Secrétariat-Général 1926, 73). The number of members grew to cover most of the European Continent and, in 1930, the congress decided to form a formal union, the Union internationale des organes officiels de propagande touristique (UIOOPT), with a permanent president who could make its case with greater authority. ${ }^{5}$

The UIOOPT collaborated closely with the League of Nations on tourism-related matters. Intended to safeguard the peace after the First World War, the League had emerged out of the Versailles Treaty negotiations. Although it was grounded in compromise, and the impulses pulling in different directions would ultimately render it impotent in international conflict resolution, the League nevertheless embodied the internationalist spirit more than any other intergovernmental forum or NGO at the time. It embraced the Wilsonian principle of national selfdetermination, but this made the question of culture and cultural borders a thorny one (Manela 2007, 127). Culture could underpin claims to self-determination and was a dangerous weapon in the hands of those squaring up for border disputes, so the original pact ignored it altogether. Ethnographers and folklorists nevertheless managed to win support for international collaboration on culture-related matters in 1922, and in 1928 an international congress was held under the auspices of a League of Nations consulting commission. There was a delighted response to the League's support. A Belgian journal considered it 'highly possible that this congress will be an effective tool for universal peace. [Folk] art will increasingly become the flower of peace' (Rogan 2006, 10). The logic of the argument was that the congress would uncover the shared roots of diverse folklore traditions, and so 'serve as an element of reconciliation, the awakening, in some way or other, of a source of friendship, stronger than any diplomatic approach' (Rogan 2006, 10). In reality, however, the conference provided a stage for the presentation of annexation claims rooted in folklore studies and ethnographic 'research'. The entanglement of European ethnology with competing nationalisms thus ended up confirming the worst fears of the League of Nations (Rogan 2008). UIOOPT's cultural internationalism also faced challenges from the new authoritarian leaders. In 1931 and 1937, Mussolini

5. Soerabaiasch Handelsblad (1930) Een vreemdelingenverkeer, 12 November. 
and Hitler hosted the UIOOPT's annual congresses, and, according to the account of the longstanding Norwegian delegate Gunnar Lampe, unsuccessfully sought to win them over (Lampe 1953, 155-156).

The outbreak of the Second World War dented internationalist hopes, but only more deeply underlined the importance of building a lasting peace. It was thought the travel industry would play an important role. As The Times reckoned in July 1941, 'When peace comes, [Thomas Cook's] will have a great work to do for civilisation in helping to reopen the channels of intercourse between the nations' (Brendon 1991, 279). In Nazi-occupied Denmark, the labour movement's travel agency, Dansk Folkeferie, insisted that by 'getting to know each other better ... our children and grandchildren will not experience the same Ragnarök that our generation has had to endure' (Warschawsky 2008, 5). Once the end of the war was in sight, Sweden's social-democratic internationalists encouraged Swedish post-war tourists to travel to the Continent 'to build friendship with the wartormented people!' (Bechmann Pedersen 2019, 230).

Internationalism also guided the pioneers of tourism studies. In 1946, the first issue of The Tourist Review appeared. A quadrilingual, Swiss-based journal dedicated to the promotion and study of tourism, this edition included 'A Plea for International Understanding' by Douglas Hacking, who emphasised that 'Never in the history of the world has the need for international understanding and amity been more urgent than it is now' (Lord Hacking 1946, 9). The remedy, however, was obvious. 'There is one easy way by which nations may come to understand each other, and that way is a reciprocal interchange of tourists' (Lord Hacking 1946, 8). A year later, the Marshall Plan was announced to help reconstruct European industry and infrastructure. Tourism offered an easy way of counterbalancing the European trade deficit with the US. Consequently, a great deal of effort was put into selling European holidays to Americans. Investment in infrastructure, hotels, and advertisement paid off, and boosted especially the French tourist industry (Endy 2004).

The European NTOs revived the interwar UIOOPT collaboration at a congress in The Hague in early 1947. Later that year, in London, the union was reorganised as the International Union of Official Travel Organisations (IUOTO), and NTOs from other continents began to join. In the summer of 1948, the Europeans formed a new chapter of the IUOTO called the European Travel Commission (ETC) to lobby for the tourist industry and to coordinate the promotion of holidays in Europe (Schipper et al. 2018). Early on, the ETC adopted the slogan 'Understanding through travel is the passport to peace'. This slogan was also embraced by the Economic Cooperation Administration (ECA), the US government agency set up to manage the Marshall Plan. In 1950, the ECA helped run a competition for posters that advertised travel as the passport to peace (McKenzie 2003, 48). At the same time, comparative freedom of movement and statutory paid leave were thought to be the West's best cultural weapons against the Communist East. As L.J. Lickorish of the British Travel and Holiday Association put it in The Tourist Review in 1951, 'on all counts it is 
reasonable to claim that the tourist and holiday movements are an essential part of the economic bulwark and defence mechanism with which the Western world is fighting the Cold War' (Lickorish 1951, 159). Less than a decade after the Second World War had ended, international and intergovernmental collaboration on tourist matters was in full swing. The post-war growth of international tourism was widely regarded as a proof of the West's superiority in the Cold War.

\section{Tourism in the Cold War}

In the early years of the Cold War, Soviet leaders primarily conceived of international mobility as a threat to national security. The newly installed communist regimes across Central and Eastern Europe overrode the pre-war tradition of reasonably open international travel, and made tourist visits to their countries next to impossible. Tellingly, Temple Fielding's best-selling Travel Guide to Europe - first published in 1948 and reprinted many times since - contained only the briefest of entries for the countries east of the Iron Curtain, and all of them centred on the new obstacles to travel (Fielding 1951).

After Stalin's death in 1953, however, measures were taken in the Soviet Union and its European buffer states to open up to Western tourists again. Khrushchev's discourse of mutual respect and peaceful coexistence proved fully compatible with the optimistic view of tourism as a vehicle for peace and mutual understanding. In August 1955, the first Western tourists were allowed into the Soviet Union, and one month later the first Soviet tourists were permitted a trip to the West (Bechmann Pedersen 2019, 234-235).

The gradual thaw in East-West tourism continued in 1957, despite the spike in international tension caused by the Hungarian Uprising and the Suez Crisis. That year, over a hundred diplomats and travel industry representatives from 29 countries converged on Prague for a five-day conference on international tourism. Despite being organised by the state-run Czechoslovak Travel Bureau (Čedok) and primarily intended to promote Czechoslovak tourism, the conference also aimed simply to facilitate contact and sow the seeds of future collaboration between airlines, railways, and tourist associations of all continents. In the opening address, Čedok's director entertained the hope that the conference would 'contribute to the expansion of international tourism and to the strengthening of that ideal which is so dear to all of us - the ideal of peace and undisturbed work for us all. ${ }^{6}$ In a subsequent debate, an Air France participant welcomed the chance for representatives from East and West to meet at the conference and urged that an increase in tourism would 'foster international friendship'. ${ }^{7}$ Shortly before the Prague conference, the travel bureaus of the socialist states had held a separate meeting in Carlsbad where they concluded that 'the most effective path to mutual understanding and comprehension is for nations to

6. Czech National Archives (NA), Státní úřad plánovací II (SUP II), 1177, 471. Bulletin no. 2 (23 October 1957).

7. NA, SUP II, 1177, 471. Bulletin no. 4 (24 October 1957). 
speak to nations in the most direct manner, by tourism. ${ }^{8}$ In the following years, the Warsaw Pact countries also began to open up for tourism inside the bloc. Improved relations later resulted in the 'borders of friendship' project between Czechoslovakia, East Germany, and Poland, which saw tens of millions of their citizens travel with relative ease between the three countries (Keck-Szajbel 2013).

Six years after the tourist conference in Prague, tourism across the East-West divide was growing steadily, benefiting from the de-Stalinisation of Eastern Europe (Bechmann Pedersen 2018). On the international scene, tourism was once again hailed for its peace-making qualities at a 1963 UN conference in Rome on international travel and tourism. The conference passed a resolution that highlighted tourism's contribution to the 'promotion of international good will and understanding and to the preservation of peace between peoples' (UN 1964, 17). A few years later, the UN General Assembly declared 1967 the International Tourist Year under the motto 'Tourism, Passport to Peace' - a variation on the original ETC catchphrase.

From that point on, the putative positive effects of tourism on interpersonal understanding and international relations attained a seemingly unquestionable status. When the East European tourist bureaus met in Bucharest in 1970, they again declared tourism 'one of the most important instruments of strengthening mutual appreciation' (Wolter 2005, 6). Tourism was included in the Helsinki Final Act's second basket on economic cooperation, which repeated 'the contribution made by international tourism to the development of mutual understanding among peoples' (Organization for Security and Co-operation in Europe 1975, 32). Although a 1983 review of the Helsinki process's contribution to the promotion and facilitation of tourism concluded that 'progress has been slow and tangible results limited', the industry did not hesitate to repeat the mantra (Ronkainen 1983, 425). In 1980, the UNWTO (IUOTO's new name after its reorganisation as an intergovernmental body in 1975) adopted the Manila Declaration on World Tourism, which stated that 'world tourism can be a vital force for world peace and can provide the moral and intellectual basis for international understanding and interdependence' (World Tourism Organization 1980, 1).

In 1988, the tourist industry upped the ante again. Under the motto 'Tourism - A Vital Force for Peace', 500 industry professionals, academics, diplomats, and NGOs from 64 countries convened for five days in Vancouver. In addition to their warm words of encouragement in the conference programme, discussed earlier, Ronald Reagan and Pope John Paul II also sent pre-recorded messages of support, expressing their hopes for tourism's peacebuilding effects (Goldner 1989). The conference marked the zenith of the peace-through-tourism euphoria described by Moufakkir and Kelly. However, as I have shown here, by then the idea that peace could be achieved through tourism was anything but novel. In fact, it had been ingrained in the international coordination of tourism from the very outset, back in the early twentieth century. 


\section{Tourism Studies Revisited}

The academic literature on tourism in the 1970s did little to query the tourism-peace nexus. On the contrary, one of the pioneering tourism textbooks stated in 1974 that 'in creating a better appreciation of other people's ways of life and institutions, tourism may create goodwill for a country' (Burkart and Medlik 1974, 57). While this was undoubtedly true, the author did nothing to problematise the underlying assumptions of the tourism-peace nexus, nor to consider the necessary conditions behind the creation of goodwill for entire countries. In an often-quoted literature review published in 1984, Erik Cohen scrutinised the claim that tourism 'improves international understanding', and concluded that thus far its advocates and opponents alike had only meagre evidence to show (Cohen 1984, 381). In other words, the jury was still out. With the 1988 convention's bold canonisation of tourism, however, tourism scholars finally began to question the industry's impact in creating world peace. As a direct response to the Vancouver conference, two tourism researchers pointed out the obvious: 'The danger in considering relations between peace and tourism is of reversing causation. Tourism is an institution that does not prosper in the absence of peace. This observation precludes the prospect that tourism causes peace' (Burnett and Uysal 1990, 2).

In the decades since the Vancouver conference, tourism research has finally questioned the tourism-peace nexus and largely put to rest the idea that a thriving tourism industry by default reduces societal conflicts (Askjellerud 2003). The latest trends in the tourism-peace field have been to meticulously study under which specific circumstances the beneficial potential of tourism might be unlocked. It is now clear that the 'Tourism, Passport to Peace' discourse, rooted in internationalist idealism, was often used as a guise for far less noble purposes. The Communist regimes in Eastern Europe appealed to mutual understanding and international peace when they opened to Western tourism, yet the driving force behind the rapprochement was their shortage of hard currency (Taylor 2011, 14). The passport-topeace slogan may have given a broad social legitimacy to the budding international tourist industry of the early post-war years, and in later years the unprecedented intensification of mobility and tourism in Europe undoubtedly strengthened peaceful relations through increased economic interdependence. Whether tourism can help overcome cultural divides and foster peaceful relations in more volatile contexts, however, is an entirely different question.

\section{Acknowledgement}

This work was supported by the Swedish Research Council under grant number 2016-06615.

\section{References}

Allport G (1954) The Nature of Prejudice. Cambridge, MA: Addison-Wesley. Askjellerud S (2003) The tourist: a messenger of peace? Annals of Tourism Research 30(3), 741-744. http://doi.org/10.1016/S0160-7383(03)00049-5. 
Bechmann Pedersen S (2018) Eastbound tourism in the Cold War: the history of the Swedish communist travel agency Folkturist. Journal of Tourism History, 10(2), 130-145. doi.org/10.1080/1755182X.2018.1469679.

Bechmann Pedersen S (2019) A paradise behind the curtain: selling eastern escapes to Scandinavians. In Hoenig B and Wadle H (eds), Eden für jeden? Touristische Sehnsuchtsorte in Mittel- und Osteuropa von 1945 bis zur Gegenwart. Göttingen: V\&R Unipress, pp. 227-249.

Blanchard L-A and Higgins-Desbiolles F (eds) (2013) Peace through Tourism: Promoting Human Security through International Citizenship. New York: Routledge.

Brendon P (1991) Thomas Cook: 150 Years of Popular Tourism. London: Secker \& Warburg.

Brown F (1989) Is tourism really a peacemaker? Tourism Management 10(4), 270-271.

Burkart AJ and Medlik S (1974) Tourism: Past, Present, and Future. London: Heinemann.

Burnett GW and Uysal M (1990) On the nature of peace in relationship to tourism: three cases. The Tourist Review 45(1), 2-7.

Buzard J (1993) The Beaten Track: European Tourism, Literature, and the Ways to Culture, 1800-1918. Oxford: Oxford University Press.

Cohen E (1984) The sociology of tourism: approaches, issues, and findings. Annual Review of sociology 10(1), 373-392.

Cohen E (2004) Contemporary Tourism: Diversity and Change. Amsterdam: Elsevier.

D'Amore L (1988) Tourism - the world's peace industry. Journal of Travel Research 27(1), 35-40. doi: 10.1177/004728758802700107.

Davidson TL (2005) What are travel and tourism: are they really an industry? In Theobald WF (ed.), Global Tourism. Amsterdam: Elsevier, pp. 25-31.

Dostoyevsky F (1988) Winter Notes on Summer Impressions. Evanston: Northwestern University Press.

Endy C (2004) Cold War Holidays: American Tourism in France. Chapel Hill: University of North Carolina Press.

Fahrmeir A (2008) Klassen-Grenzen: Migrationskontrolle im 19. Jahrhundert. Rechtsgeschichte 12, 125-138.

Farmaki A (2017) The tourism and peace nexus. Tourism Management 59, 528-540. https://doi.org/10.1016/j.tourman.2016.09.012.

Fielding T (1951) Fielding's Travel Guide to Europe. New York: William Sloane Associates.

First Global Conference (1988) Tourism - A Vital Force for Peace Program. Available at www.iipt.org/pdf/1stGlobalConference1988.pdf (accessed 21 August 2018).

Goldner CR (1989) Tourism - a vital force for peace. Tourism Management 10(2), 166-168. http://doi.org/10.1016/0261-5177(89)90058-7.

Hewstone M and Swart H (2011) Fifty-odd years of inter-group contact: from hypothesis to integrated theory. British Journal of Social Psychology 50(3), 374-386.

Higgins-Desbiolles F (2006) More than an 'industry': the forgotten power of tourism as a social force. Tourism Management 27(6), 1192-1208.

Iriye A (1997) Cultural Internationalism and World Order. Baltimore: Johns Hopkins University Press.

Iriye A (2002) Global Community: The Role of International Organizations in the Making of the Contemporary World. Berkeley and Los Angeles: University of California Press. 
John Paul II (1985) Address of Pope John Paul II to the participants in The World Travel Congress of The American Society of Travel Agents. Available at https:// w2.vatican.va/content/john-paul-ii/en/speeches/1985/november/documents/hf_jpii_spe_19851114_congresso-asta.html (accessed 10 February 2020).

Keck-Szajbel M (2013) The Borders of Friendship: Transnational Travel and Tourism in the East Bloc, 1972-1989. PhD dissertation. University of California, Berkeley.

Koshar R (2000) German Travel Cultures. Oxford: Berg.

Lampe GB (1953) Reiselivet i Norge gjennom 50 år. [Bergen]: J. Griegs boktrykkeri.

Le Secrétariat-Général (1926) Congrès international des organisations officielles de propagande touristique: tenu à Prague du 27 juin au 5 juillet 1926. The Hague.

Lickorish LJ (1951) The tourist trade and the Cold War. The Tourist Review 6(3), $157-159$.

Litvin SW (1998) Tourism: the world's peace industry? Journal of Travel Research 37(1), 63-66. doi: 10.1177/004728759803700108.

Löfgren O (1999) On Holiday: A History of Vacationing. Berkeley and Los Angeles: University of California Press.

Lord Hacking (1946) A plea for international understanding. The Tourist Review 1(1), 8-9.

Manela E (2007) The Wilsonian Moment: Self-determination and the International Origins of Anticolonial Nationalism. Oxford: Oxford University Press.

Mckenzie BA (2003) Creating a tourist's paradise: the Marshall Plan and France, 1948 to 1952. French Politics, Culture \& Society 21(1), 35-54.

Moufakkir O and Kelly I (2010a) Introduction - peace and tourism: friends not foes. In Moufakkir O and Kelly I (eds), Tourism, Progress and Peace. Wallingford: CABI, pp. xvi-xxxii.

Moufakkir O and Kelly I (eds) (2010b) Tourism, Progress, and Peace. Wallingford: CABI.

Organization for Security and Co-operation in Europe (1975) Helsinki Final Act. Available at www.osce.org/helsinki-final-act (accessed 21 August 2018).

Osterhammel J (2017) Die Flughöhe der Adler: Historische Essays zur globalen Gegenwart. Munich: CH Beck.

Pettigrew TF and Tropp LR (2006) A meta-analytic test of intergroup contact theory. Journal of Personality and Social Psychology 90(5), 751-783.

Pratt S and Liu A (2016) Does tourism really lead to peace? A global view. International Journal of Tourism Research 18(1), 82-90. doi: 10.1002/jtr.2035.

Richards G (1995) Politics of national tourism policy in Britain. Leisure Studies 14(3), 153-173.

Ritzer G and Liska A (1997) 'McDisneyization' and 'Post-Tourism': complementary perspectives on contemporary tourism. In Rojek C and Urry J (eds), Touring Cultures: Transformations of Travel and Theory. New York: Routledge, pp. 96-109.

Rogan B (2006) Folk art and politics in inter-war Europe: an early debate on applied ethnology. Folk Life 45(1), 7-23.

Rogan B (2008) From rivals to partners on the inter-war European scene: Sigurd Erixon, Georges Henri Rivière and the international debate on European ethnology in the 1930s. Arv 64, 61-100.

Ronkainen IA (1983) The conference on security and cooperation in Europe. Annals of Tourism Research 10(3), 415-426. http://doi.org/10.1016/0160-7383(83)90065-8.

Schipper F, Tchoukarine I and Bechmann Pedersen S (2018) The History of the European Travel Commission, 1948-2018. Brussels: The European Travel Commission.

Sluga G (2013) Internationalism in the Age of Nationalism. Philadelphia: University of Pennsylvania Press. 
Stendhal (1959) Rome, Naples and Florence. London: John Calder.

Taylor K (2011) From trips to modernity to holidays in nostalgia - tourism history in Eastern and Southeastern Europe. Tensions of Europe/Inventing Europe working paper 1 .

Tomljenovic R (2010) Tourism and intercultural understanding or contact hypothesis revisited. In Moufakkir O and Kelly I (eds) Tourism, Progress and Peace. Wallingford: CABI, pp. 17-34.

United Nations (1964) Recommendations on International Travel and Tourism. Geneva: United Nations.

Vukonić B (2012) An outline of the history of tourism theory: source material (for future research). In Hsu CHC and Gartner WC (eds), The Routledge Handbook of Tourism Research. New York: Routledge, pp. 3-27.

Warschawsky A (2008) Folkeferie - ferieformer, ferieindhold og dannelsesidealer 1938-1988. Arbejderhistorie (2), 1-16.

Wolter H (2005) 'The future bilateral and multilateral cooperation': the conferences of state authorities for tourism in socialist countries, 1966 till 1988. Paper presented at the Third International Conference on the History of Transport, Traffic and Mobility. York, 6-9 October.

World Tourism Organization (1980) Manila Declaration on World Tourism. Available at www.e-unwto.org/doi/pdf/10.18111/unwtodeclarations.1980.6.4.1 (accessed 21 August 2018).

World Tourism Organization (2017) UNWTO Tourism Highlights. Available at www.e-unwto.org/doi/pdf/10.18111/9789284419029 (accessed 21 August 2018).

Zahra T (2016) The Great Departure: Mass Migration from Eastern Europe and the Making of the Free World. New York: WW Norton.

Zuelow EGE (2015) A History of Modern Tourism. London: Palgrave.

\section{About the Author}

Sune Bechmann Pedersen is a visiting researcher at the University of Amsterdam School for Regional, Transnational and European Studies and a researcher at the Department of Communication and Media, Lund University. His research focuses on the history of mobility, media, and memory in twentieth-century Europe. 